\title{
PENGARUH POLA PENGASUHAN ORANGTUA DAN PROSES PEMBELAJARAN DI SEKOLAH TERHADAP TINGKAT KREATIVITAS ANAK PRASEKOLAH (4-5 TAHUN)
}

\author{
Dian Novita \\ Muman Hendra Budiman \\ Universitas Terbuka \\ e-mail: d.novita@ecampus.ut.ac.id
}

\begin{abstract}
Preschoolers are creative people, unfortunately many parents and teachers are less aware or less can appreciate the creativity of children. They would want a child who is always obedient and do the things parents want or do the same things as other children. Services to early childhood education is a fundamental influence on the development of further child to adult. Hurlock (1991) says that the early years of a child's life is the basis which tends to persist and influence the attitudes and behavior of children throughout his life. At preschool age, children have the nature of imitation or copying of anything he had seen. This study aims to determine the effect characteristic of the individual and family characteristic to the creativity and parenting parents and the learning process at school on the level of creativity of kindergarten age children. The method used in this study was a cross sectional study. Guide TK Ananda Open University with a sample of 30 children. Data obtained through observation, interviews and documentation. From the research results can be seen that the gender and birth order of the child has no correlation with parenting styles applied to the elderly at home. Family characteristics did not correlate with their parenting styles on children, as well as the characteristics of the child with the child's creativity. There is a significant relationship between education fathers with children's creativity in the face of boredom, while also shown a significant relationship between the mother opinion in answering the questions in the children's play activities that can improve creativity. There is a significant correlation between parental care provided to the ability of a child's imagination, familiar surroundings, answering questions posed from child to improve the child's ability to experiment, creating new stimuli children so that children have the ability to overcome boredom.
\end{abstract}

Keywords: children kindergarten, creativity, learning, parenting parents.

\begin{abstract}
ABSTRAK
Anak prasekolah adalah individu yang kreatif, sayangnya banyak orang tua dan guru yang kurang menyadari atau kurang dapat menghargai kreativitas anak. Mereka lebih menginginkan anak yang selalu patuh dan melakukan hal-hal yang diinginkan orang tua atau melakukan hal-hal yang sama seperti anak lain. Layanan pendidikan kepada anak usia dini merupakan dasar yang sangat berpengaruh terhadap perkembangan anak selanjutnya hingga dewasa. Hurlock (1991) mengatakan bahwa tahun-tahun awal kehidupan anak merupakan dasar yang cenderung bertahan dan mempengaruhi sikap dan perilaku anak sepanjang hidupnya. Pada usia pra sekolah, anak mempunyai sifat imitasi atau meniru terhadap apapun yang telah dilihatnya. Penelitian ini bertujuan untuk mengetahui pengaruh
\end{abstract}


karakteritik individu dan karakteritik keluarga terhadap kreativitas dan pola asuh orang tua dan proses pembelajaran di sekolah terhadap tingkat kreativitas anak usia TK. Metode yang digunakan dalam penelitian ini adalah cross sectional studi. Dilakukan di TK Ananda Universitas Terbuka dengan jumlah sampel 30 anak. Data diperoleh melalui observasi, wawancara dan studi dokumentasi. Dari hasil penelitian dapat dilihat bahwa jenis kelamin dan urutan kelahiran anak tidak memiliki korelasi dengan gaya pengasuhan yang diterapkan orang tua di rumah. Karakteristik keluarga tidak memiliki korelasi dengan gaya pengasuhan mereka terhadap anak, begitu juga anak dengan karakteristik anak terhadap kreativitas. Terdapat hubungan yang siginifikan antara pendidikan ayah dengan kreativitas anak dalam menghadapi rasa bosan, selain itu juga terlihat hubungan signifikan antara pendapat ibu dengan dalam menjawab pertanyaan-pertanyaan anak dalam kegiatan bermain yang dapat meningkatkan kreativitas. Terdapat hubungan signifikan antara pengasuhan yang diberikan orang tua terhadap kemampuan imajinasi anak, mengenal lingkungan sekitar, menjawab pertanyaan yang dilontarkan dari anak sehingga meningkatkan kemampuan anak untuk bereksperimen, menimbulkan rangsangan-rangsangan baru anak sehingga anak memliki kemampuan dalam mengatasi rasa bosan.

Kata kunci: anak taman kanak-kanak, kreativitas, pola asuh orang tua, proses pembelajaran.

Hal terpenting yang harus disadari oleh orang tua dan guru ialah bahwa setiap orang memiliki potensi kreatif. Beberapa orang memilikinya lebih dari orang lain, tetapi tak ada orang yang tidak kreatif sama sekali. Terutama anak-anak usia prasekolah, sebetulnya sangat kreatif, mereka memiliki kreativitas alamiah. Sayangnya banyak orang tua dan guru yang kurang menyadari atau kurang dapat menghargai kreativitas anak. Mereka lebih menginginkan anak yang selalu patuh dan melakukan hal-hal yang diinginkan orang tua atau melakukan hal-hal yang Sama seperti anak lain. Orisinalitas kurang dapat diterima, dianggap menyulitkan, dan bahkan dapat berbahaya.

Anggapan bahwa pendidikan baru bisa dimulai setelah usia sekolah dasar yaitu usia tujuh tahun ternyata tidaklah benar. Bahkan pendidikan yang dimulai pada usia TK (4-6 tahun) pun sebenarnya sudah terlambat. Hasil penelitian di bidang neurologi yang dilakukan Benyamin $\mathrm{S}$. Bloom, seorang ahli pendidikan dari Universitas Chicago, Amerika Serikat, menunjukkan bahwa pertumbuhan sel jaringan otak pada anak usia 0-4 tahun mencapai 50\%, hingga usia 8 tahun mencapai $80 \%$. Artinya bila pada usia tersebut otak anak tidak mendapatkan rangsangan yang maksimal maka otak anak tidak akan berkembang secara optimal. Data memperlihatkan bahwa layanan pendidikan anak usia dini di Indonesia masih termasuk sangat memprihatinkan. Sampai dengan tahun 2001 (Jalal, 2003: 20) jumlah anak usia 0-6 tahun di Indonesia yang telah mendapatkan layanan pendidikan baru sekitar 28\% (7.347.240 anak). Khusus untuk anak usia 4-6 tahun, masih terdapat sekitar 10,2 juta $(83,8 \%)$ yang belum mendapatkan layanan pendidikan. Layanan pendidikan kepada anak-anak usia dini merupakan dasar yang sangat berpengaruh terhadap perkembangan anak selanjutnya hingga dewasa. Hal ini diperkuat oleh Hurlock (1991: 27) bahwa tahun-tahun awal kehidupan anak merupakan dasar yang cenderung bertahan dan mempengaruhi sikap dan perilaku anak sepanjang hidupnya.

Kreativitas merupakan salah satu potensi yang dimiliki anak yang perlu dikembangkan sejak usia dini. Setiap anak memiliki bakat kreatif dan ditinjau dari segi pendidikan, bakat kreatif dapat dikembangkan dan karena itu perlu dipupuk sejak dini 
Diungkapkan oleh Munandar (2004: 94) bahwa penelitian menunjukkan hubungan yang erat antara sikap bermain dan kreativitas. Namun, jelas Froebel (Patmonodewo, 2003: 7), bermain tanpa bimbingan dan arahan serta perencanaan lingkungan di mana anak belajar akan membawa anak pada cara belajar yang salah atau proses belajar tidak akan terjadi. la mengisyaratkan bahwa dalam proses pembelajaran, pendidik bertanggung jawab dalam membimbing dan mengarahkan anak agar menjadi kreatif

Tujuan umum penelitian ini adalah untuk mengetahui pengaruh pola asuh, proses pembelajaran terhadap tingkat kreativitas anak usia TK di TK Ananda UT Pondok Cabe kota Tangerang Selatan. Lebih jauh, tujuan penelitian ini adalah untuk 1) Mengetahui pengaruh karakteristik individu dan karakteristik keluarga terhadap tingkat kreativitas anak usia TK; 2) Mengetahui pengaruh pola asuh orang tua terhadap tingkat kreativitas anak usia TK; 3) Mengetahui pengaruh proses pembelajaran di sekolah terhadap tingkat kreativitas anak usia TK; 4) Mengetahui perbedaan sebagai akibat dari pola asuh orang tua dengan tingkat kreativitas anak atau proses pembelajaran di sekolah dengan tingkat kreativitas anak dan kombinasi dari pola asuh dan proses pembelajaran di sekolah dengan tingkat kreativitas anak usia TK; serta 5) Mengetahui apakah ada hubungan antara jenis kelamin, usia anak, pekerjaan orang tua, dan penghasilan orang tua terhadap tingkat kreativitas anak usia TK.

Orang tua adalah komponen keluarga yang terdiri dari ayah dan ibu, dan merupakan hasil dari sebuah ikatan perkawinan yang sah yang dapat membentuk sebuah keluarga. Orang tua memiliki tanggung jawab untuk mendidik, mengasuh dan membimbing anak-anaknya untuk mencapai tahapan tertentu yang menghantarkan anak untuk siap dalam kehidupan bermasyarakat. Pengertian orang tua tersebut, tidak terlepas dari pengertian keluarga, karena orang tua merupakan bagian keluarga besar yang sebagian besar telah tergantikan oleh keluarga inti yang terdiri dari ayah, ibu dan anak-anak. Secara tradisional, keluarga diartikan sebagai dua atau lebih orang yang dihubungkan dengan pertalian darah, perkawinan atau adopsi (hukum) yang memiliki tempat tinggal bersama. Sedang Morgan dalam Sitorus (1988: 45) menyatakan bahwa keluarga merupakan suatu grup sosial primer yang didasarkan pada ikatan perkawinan (hubungan suami-istri) dan ikatan kekerabatan (hubungan antar generasi, orang tua-anak) sekaligus. Namun secara dinamis individu yang membentuk sebuah keluarga dapat digambarkan sebagai anggota dari grup masyarakat yang paling dasar yang tinggal bersama dan berinteraksi untuk memenuhi kebutuhan individu maupun antar individu mereka.

Suparlan (1993: 76) mendefinisikan keluarga merupakan kelompok sosial yang terdiri dari ayah, ibu dan anak. Hubungan sosial diantara anggota keluarga relatif tetap dan didasarkan atas ikatan perkawinan, darah atau adopsi. Hubungan antara anggota keluarga dijiwai oleh suasana kasih sayang dan rasa tanggung jawab. Dari beberapa paparan pendapat tersebut, dapat disimpulkan bahwa peran orang tua adalah fungsi yang dimainkan oleh orang tua yang berada pada posisi atau situasi tertentu dengan karakteristik atau kekhasan tertentu pula.

Keluarga merupakan kelompok sosial yang pertama dimana anak dapat berinteraksi. Pengaruh keluarga dalam pembentukan dan perkembangan kepribadian sangatlah besar artinya. Banyak faktor dalam keluarga yang ikut berpengaruh dalam proses perkembangan anak. Salah satu faktor dalam keluarga yang mempunyai peranan penting dalam pembentukan kepribadian adalah praktik pengasuhan anak. Hal tersebut dikuatkan oleh pendapat Brown (1961:76) yang mengatakan bahwa keluarga adalah lingkungan yang pertama kali menerima kehadiran anak. Orang tua mempunyai berbagai macam fungsi yang salah satu di antaranya ialah mengasuh putra-putrinya. Dalam mengasuh anaknya, orang tua dipengaruhi oleh budaya yang ada di lingkungannya. Di 
samping itu, orang tua juga diwarnai oleh sikap-sikap tertentu dalam memelihara, membimbing, dan mengarahkan putra-putrinya. Sikap tersebut tercermin dalam pola pengasuhan kepada anaknya yang berbeda-beda, karena orang tua mempunyai pola pengasuhan tertentu. Pola asuhan itu menurut Stewart dan Koch (1983: 178) terdiri dari tiga kecenderungan pola asuh orang tua yaitu:

a. Pola asuh otoriter, pola asuh ini cenderung menetapkan standar yang mutlak harus dituruti, biasanya dibarengi dengan ancaman-ancaman. Apabila anak tidak mau melakukan apa yang dikatakan oleh orang tua, maka orang tua tipe ini tidak segan menghukum anak. Orang tua tipe otoriter tidak mengenal kompromi, dan dalam komunikasi biasanya bersifat satu arah. Orang tua tipe otoriter tidak memerlukan umpan balik dari anaknya untuk mengerti mengenai anaknya.

b. Pola asuh demokratis adalah pola asuh yang memprioritaskan kepentingan anak, akan tetapi tidak ragu-ragu mengendalikan mereka. Orang tua dengan pola asuh ini bersikap rasional, selalu mendasari tindakannya pada rasio atau pemikiran-pemikiran. Orang tua tipe ini juga bersikap realistis terhadap kemampuan anak, tidak berharap yang berlebihan yang melampaui kemampuan anak. Orang tua tipe ini juga memberikan kebebasan kepada anak untuk memilih dan melakukan suatu tindakan, dan pendekatannya kepada anak bersifat hangat

c. Pola asuh permisif adalah biasanya memberikan pengawasan yang sangat longgar.

Memberikan kesempatan pada anaknya untuk melakukan sesuatu tanpa pengawasan yang cukup darinya. Mereka cenderung tidak menegur atau memperingatkan anak apabila anak sedang dalam bahaya, dan sangat sedikit bimbingan yang diberikan oleh mereka. Namun orang tua tipe ini biasanya bersifat hangat, sehingga seringkali disukai oleh anak

Pentingnya bermain bagi perkembangan kepribadian telah diakui secara universal, karena merupakan salah satu kebutuhan dasar manusia, baik bagi anak maupun orang dewasa. Kesempatan bermain dan rekreasi memberikan anak kegembiraan disertai kepuasan emosional. Bermain merupakan kegiatan yang spontan dan kreatif, yang dengannya seseorang dapat menemukan ekspresi dirinya sepenuhnya. (Freeman \& Munandar, 1997:262). Sebagaimana terdapat dalam Garis-Garis Besar Program Kegiatan Belajar Taman Kanak-kanak (Depdikbud, 1994) tujuan program kegiatan belajar anak TK adalah untuk membantu meletakkan dasar ke arah perkembangan sikap, pengetahuan, keterampilan, dan daya cipta yang diperlukan oleh anak didik dalam menyesuaikan diri dengan lingkungannya dan untuk pertumbuhan serta perkembangan selanjutnya. Sedangkan ruang lingkup program kegiatan belajar meliputi: pembentukan perilaku melalui pembiasaan dalam pengembangan moral pancasila, agama, disiplin, perasaan/emosi, dan kemampuan bermasyarakat, serta pengembangan kemampuan dasar melalui kegiatan yang dipersiapkan oleh guru meliputi pengembangan kemampuan bahasa, daya pikir, daya cipta, ketrampilan dan jasmani

Istilah kreativitas berasal dari bahasa Inggris "to create" yang berarti mencipta, yaitu mengarang atau membuat sesuatu yang berbeda baik bentuk, susunan atau gaya dari yang lazim dikenal orang. Perbedaan bentuk, susunan dan gaya yang dicipta merupakan pembaharuan dengan atau tanpa mengubah fungsi dari kerangka itu (Soemardjan, 1983). Dengan demikian, kreativitas dapat diartikan sebagai kemampuan untuk mencipta suatu produk baru antara unsur-unsur yang ada. Ciptaan tidak perlu seluruh produk harus baru, dapat juga gabungan kombinasi dari unsur yang sudah ada sebelumnya (Semiawan, 1999). Kreativitas tidak hanya diartikan sebagai kamampuan untuk mencipta sesuatu baik yang bersifat baru maupun yang kombinasi. Munadi (1987) memberikan pengertian lain mengenai kreativitas sebagai proses berpikir yang membawa seseorang berusaha menentukan metode dan cara baru di dalam memecahkan suatu masalah, kemudian ia menekankan 
bahwa kreativitas yang penting bukan apa yang dihasilkan dari proses tersebut tetapi yang pokok adalah kesenangan dan keasyikan yang terlihat dalam melakukan aktivitas kreatif.

Hal lain di ungkapkan oleh Harlock (1987) dimana proses berfikir dalam kreativitas bertujuan untuk menciptakan sesuatu yang baru, berbeda, unik, timbul dari pemikiran divergen serta tergantung dari pengalaman/pengetahuan yang diperoleh dan berbentuk imajinasi yang dikendalikan yang menjurus kearah beberapa bentuk prestasi seperti melukis, menyusun balok atau sekedar melamun.

Munandar (1988) menyebutkan bahwa perkembangan kreativitas dipengaruhi oleh dua faktor, yaitu:

a. Faktor internal, yaitu faktor yang berasal dari atau terdapat pada diri individu yang bersangkutan. Faktor ini meliputi keterbukaan, locus of control yang internal, kemampuan untuk bermain atau bereksplorasi dengan unsur-unsur, bentuk-bentuk, konsep-konsep, serta membentuk kombinasi-kombinasi baru berdasarkan hal-hal yang sudah ada sebelumnya.

b. Faktor eksternal, yaitu faktor yang berasal dari luar diri individu yang bersangkutan. Faktorfaktor ini antara lain meliputi keamanan dan kebebasan psikologis, sarana atau fasilitas terhadap pandangan dan minat yang berbeda, adanya penghargaan bagi orang yang kreatif, adanya waktu bebas yang cukup dan kesempatan untuk menyendiri, dorongan untuk melakukan berbagai eksperimen dan kegiatan-kegiatan kreatif, dorongan untuk mengembangkan fantasi kognisi dan inisiatif serta penerimaan dan penghargaan terhadap individual

Penelitian ini menggunakan desain cross sectional Penentuan daerah lokasi studi tidak dilakukan secara acak, melainkan dilakukan dengan tujuan tertentu (purposive) berdasarkan (a) kondisi daerah, yaitu sekolah yang berada di wilayah kecamatan Pamulang (Tangerang Selatan) yaitu sebuah wilayah yang berbatasan dengan provinsi Jawa barat dan DKI. (b) kelompok siswa yang bersekolah di lingkungan tersebut memiliki latar belakang yang beragam dari pegawai eselon terendah sampai eselon tertinggi selain itu juga ada yang berlatar belakang pedagang. (c) TK Ananda adalah berstatus swasta dan menyediakan area dan fasilitas yang dapat menunjang untuk meningkatkan kreativitas anak.

Subyek penelitian adalah 30 anak usia 4-6 tahun yang bersekolah di TK Ananda. Pengumpulan data dilakukan dengan cara observasi terhadap subyek untuk melihat kemampuan kreativitas anak. Selain itu wawancara juga dilakukan terhadap beberapa narasumber seperti orang tua, anak, dan guru. Studi dokumentasi juga dilakukan sebagai pelengkap.

Jenis data yang dikumpulkan adalah Data Primer dan Data Sekunder. Data Primer meliputi: (1) Karakteristik Keluarga (usia Orang tua, besar keluarga, pendapatan orang tua, pendidikan orang tua, pekerjaan orangtua); (2) karakteristik (contoh jenis kelamin dan urutan dalam keluarga) (3) Pola pengasuhan (4) Proses pembelajaran, (5) kreativitas anak. Data sekunder meliputi: keadaan umum sekolah TK Ananda.

Analisis data yang digunakan dalam penelitian ini yaitu analisis statistika deskriptif dan analisis statistika inferensial. Analisis statistika inferensial yang digunakan adalah uji korelasi Spearman dan Pearson, serta uji beda t-test. Sementara itu dilakukan uji regresi linear berganda untuk menganalisis variable-variabel yang mempengaruhi kreativitas.

\section{HASIL DAN PEMBAHASAN}

Pada penelitian ini karakteristik individu yang digunakan adalah anak yang berada pada rentang usia 4-6 tahun yang bersekolah di TK, yang memiliki orang tua lengkap dan bersekolah di TK 
Ananda Universitas Terbuka serta berada di kelas B. Terlihat pada Tabel 1 yaitu anak yang berada pada usia 4 tahun ada sebanyak 30\%, dan anak yang berada pada usia 5 tahun sebanyak $47 \%$ sedangkan anak yang berusia 6 tahun ada sebanyak 23\% dari keseluruhan total responden.

Tabel 1. Anak Yang Berada pada Rentang Usia 4-6 Tahun

\begin{tabular}{lcc}
\hline Usia Anak & \multicolumn{2}{c}{ Karakteristik Individu } \\
\cline { 2 - 3 } & $\mathrm{n}$ & $\%$ \\
\hline 4Tahun & 9 & 30 \\
5 Tahun & 14 & 47 \\
6 Tahun & 7 & 23 \\
\hline \multicolumn{1}{r}{ Jumlah } & 30 & 100 \\
\hline
\end{tabular}

Kebanyakan responden dalam penelitian ini adalah anak perempuan yaitu $57 \%$ dan anak laki-laki sebanyak 43\% dari total responden sebanyak 30 orang anak, terlihat seperti pada Tabel 2.

Tabel 2. Total Responden Anak

\begin{tabular}{lcc}
\hline Jenis Kelamin & \multicolumn{2}{c}{ Karakteristik Individu } \\
\cline { 2 - 3 } & $\mathrm{n}$ & $\%$ \\
\hline Perempuan & 17 & 57 \\
Laki-laki & 13 & 43 \\
\hline Jumlah & 30 & 100 \\
\hline
\end{tabular}

Sedangkan jika dilihat dari urutan kelahiran kebayakan anak berada pada urutan kelahiran pertama yaitu sebanyak $53 \%$ anak dan anak yang berada pada urutan kelahiran kedua ada sebanyak $23 \%$, lalu anak yang berada pada urutan kelahiran ke tiga ada sebanyak $13 \%$ sedangkan anak yang berada pada urutan kelahiran ke empat memiliki persentase yang lebih sedikit yaitu sebanyak 3\% dari total keseluruhan responden hal ini dapat dilihat pada Tabel 3.

Tabel 3. Urutan Kelahiran

\begin{tabular}{ccc}
\hline Urutan Kelahiran & \multicolumn{2}{c}{ Karakteristik Individu } \\
\cline { 2 - 3 } & $\mathrm{n}$ & $\%$ \\
\hline 1 & 16 & 53 \\
2 & 7 & 23 \\
3 & 4 & 13 \\
4 & 1 & 3 \\
\hline Jumlah & 30 & 100 \\
\hline
\end{tabular}

Kebanyakan usia jumlah anggota keluarga orang tua yang menyekolahkan anaknya di TK Ananda adalah keluarga kecil, yaitu sebanyak $77 \%$ dengan kisaran 1-4 anggota keluarga dan keluarga yang memiliki jumlah anggota 5-6 orang yang dikategorikan sebagai keluarga menengah ada sebanyak $23 \%$, sedangkan untuk keluarga besar dengan jumlah anggota lebih dari 7 orang tidak ada terlihat pada Tabel 4 . 
Tabel 4. Karakteristik Keluarga

\begin{tabular}{lcc}
\hline Karakteristik Keluarga & \multicolumn{2}{c}{ Besar Keluarga } \\
\cline { 2 - 3 } & $\mathrm{n}$ & $\%$ \\
\hline Keluarga kecil & 23 & 77 \\
Keluarga menengah & 7 & 23 \\
Keluarga Besar & 0 & 0 \\
\hline Jumlah & 30 & 100 \\
\hline
\end{tabular}

Rata-rata usia Ayah adalah 29-35 tahun dengan dan Ibu 27-35 tahun, sebagian besar umur Ayah dan Ibu termasuk kelompok umur 31-40 tahun, yaitu kelompok usia relatif muda dan produktif. Pada keadaan umur ini pasangan Ayah dan Ibu dapat memberikan peluang yang lebih besar bagi upaya peningkatan pendapatan, pengoptimalan pemanfaatan untuk memfasilitasi anak dengan menyediakan berbagai media dan kebutuhan anak untuk meningkatkan kemampuan kreativitas anak.

Dari data yang diperoleh sebagian besar ayah memiliki pendidikan yang tinggi pada jenjang pendidikan tingkat perguruan tinggi yaitu sebanyak 26 orang sekitar $87 \%$, kemudian ada sebanyak $13 \%$ ayah yang memiliki pendidikan lulusan SMA yaitu sebanyak 4 orang, sedangkan untuk ayah yang tidak tamat SD, SMP tidak terlihat. Lain halnya dengan pendidikan ibu, di sini terlihat ada sekitar 8 orang yaitu sekitar $27 \%$ ibu yang memiliki pendidikan lulusan SMA dan ibu yang memiliki pendidikan tinggi di jenjang pendidikan perguruan tinggi terlihat sebesar $73 \%$ yaitu sebanyak 22 orang. Dengan perkataan lain, sebagian besar pendidikan orang tua anak adalah lulusan Perguruan Tinggi terlihat pada Tabel 5.

Tabel 5. Pendidikan Orang Tua

\begin{tabular}{ccccc}
\hline \multirow{2}{*}{ Pendidikan } & \multicolumn{2}{c}{ Ayah } & \multicolumn{2}{c}{$\mathrm{lbu}$} \\
\cline { 2 - 5 } & $\mathrm{n}$ & $\%$ & $\mathrm{n}$ & $\%$ \\
\hline Tidak Tamat SD & 0 & 0 & 0 & 0 \\
SD/Sederajat & 0 & 0 & 0 & 0 \\
SMP/sederajat & 0 & 0 & 0 & 0 \\
SMA/sederajat & 4 & 13 & 8 & 27 \\
Perguruan Tinggi & 26 & 87 & 22 & 73 \\
\hline Jumlah & 30 & 100 & 30 & 100 \\
\hline
\end{tabular}

Tabel 6. Pekerjaan Orang Tua

\begin{tabular}{ccccc}
\hline \multirow{2}{*}{ Pekerjaan } & \multicolumn{2}{c}{ Ayah } & \multicolumn{3}{c}{ lbu } \\
\cline { 2 - 5 } & $\mathrm{n}$ & $\%$ & $\mathrm{n}$ & $\%$ \\
\hline Buruh & 0 & 0 & 0 & 0 \\
Petani & 0 & 0 & 0 & 0 \\
wiraswasta & 6 & 20 & 1 & 3 \\
Pegawai swasta & 10 & 33 & 6 & 20 \\
PNS & 14 & 47 & 5 & 17 \\
Pensiunan PNS & 0 & 0 & 0 & 0 \\
Tidak Bekerja & 0 & 0 & 18 & 60 \\
\hline Jumlah & 30 & 100 & 30 & 100 \\
\hline
\end{tabular}


Tabel 6 memperlihatkan sebagian besar pekerjaan utama ayah adalah pegawai negeri sipil yaitu ada sebanyak 14 orang sebanyak 33\%, dan ayah yang bekerja sebagai pegawai swasta sebanyak 10 orang dengan persentase $33 \%$, sedangkan ayah yang memiliki pekerjaan sendiri atau wiraswasta ada sebanyak 6 orang yaitu $20 \%$, untuk pekerjaan ayah sebagai buruh, petani, atau pensiunan PNS bahkan tidak memiliki pekerjaan dinyatakan tidak ada yaitu $0 \%$.

Jika dilihat dari Tabel 6 maka tampak kebanyakan ibu adalah ibu rumah tangga yaitu sebanyak 18 orang dengan persentase $60 \%$, kemudian diikuti oleh ibu yang bekerja sebagai pegawai swasta ada sebanyak 6 orang sekitar $20 \%$, lain halnya dengan ibu yang bekerja sebagai PNS dapat dilihat sekitar $17 \%$ yaitu sebanyak 5 orang, demikian juga terlihat ada 1 orang ibu yang memiliki pekerjaan sendiri yaitu sekitar $3 \%$ sedangkan untuk ibu yang memiliki pekerjaan sebagai buruh, petani, dan pensiunan PNS disini tidak ada.

Tabel 7. Korelasi Karakteristik Anak dengan Pengasuhan:

\begin{tabular}{lr}
\hline Variabel & Pengasuhan \\
\hline Jenis kelamin & $-0,089$ \\
Urutan keluarga & 0,164 \\
\hline
\end{tabular}

Pada Tabel 7 terlihat bahwa tidak ada korelasi antara karakteristik anak dengan pengasuhan, dengan demikian, dapat dikatakan bahwa tidak ada hubungan antara jenis kelamin anak dengan urutan kelahiran dalam keluarga, artinya bahwa anak yang lahir lebih awal dengan anak lahir kemudian terhadap gaya pengasuhan yang diberikan orang tua.

Tabel 8. Korelasi Karakteristik Anak dengan Kreativitas

\begin{tabular}{|c|c|c|c|c|c|c|c|c|}
\hline Variabel & Imajinasi & Lingkungan & Pertanyaan & $\begin{array}{l}\text { Rasa } \\
\text { ingin } \\
\text { tahu }\end{array}$ & Eksperimen & $\begin{array}{l}\text { Rangsangan } \\
\text { baru }\end{array}$ & $\begin{array}{l}\text { Pengalaman } \\
\text { baru }\end{array}$ & Bosan \\
\hline $\begin{array}{l}\text { Jenis } \\
\text { kelamin }\end{array}$ & $-0,262$ & 0,072 & $-0,284$ & 0,242 & $-0,070$ & 0,094 & $-0,293$ & $-0,346$ \\
\hline $\begin{array}{l}\text { Urutan } \\
\text { keluarga }\end{array}$ & $-0,018$ & $-0,242$ & 0,173 & 0,087 & $-0,101$ & $-0,065$ & 0,193 & $-0,321$ \\
\hline
\end{tabular}

Dapat dilihat pada Tabel 8 bahwa tidak ada korelasi antara karakteristik anak dengan kreativitas, bahwa jenis kelamin anak dan urutan kelahiran dalam keluarga tidak memberikan pengaruh terhadap kreativitas anak. Artinya kemampuan kreativitas anak tidak ditemukan perbedaan antara anak pertama dan anak lahir kemudian begitu juga dengan jenis kelamin anak tidak terlihat hubungan yang nyata antara tingkat kemampuan kreativitas anak laki-laki dan anak perempuan.

Terlihat pada Tabel 9 bahwa pendidikan ayah berkorelasi dengan kreativitas anak yaitu terhadap rasa bosan, semakin tinggi pendidikan ayah maka tingkat kebosanan anak semakin sedikit dalam berkreativitas, selain itu juga terlihat bahwa semakin tinggi pendapatan ibu maka semakin terpenuhi rasa ingin tahu anak dalam melakukan kegiatan berkreativitas begitu juga semakin tinggi pendapatan ibu maka semakin tinggi tingkat kreativitas anak karena ibu dapat membelikan mainan atau media-media yang lebih banyak untuk merangsang tingkat kreativitas anak. Gunarsa (1995) mengatakan bahwa dalam keluarga yang ideal ada dua individu yang memiliki peran penting yaitu peran ayah dan peran ibu, peran ibu antara lain adalah memenuhi kebutuhan biologis dan fisik, merawat dan mengurus keluarga dengan sabar, mesra dan konsisten, mendidik, mengatur dan mengendalikan anak serta menjadi contoh dan teladan bagi anak. 
Tabel 9. Korelasi Karakteristik Keluarga dengan Kreativitas

\begin{tabular}{lcccccccc}
\hline Variabel & Imajinasi & Lingkungan & Pertanyaan & $\begin{array}{l}\text { Rasa } \\
\text { ingin } \\
\text { tahu }\end{array}$ & & Eksperimen & $\begin{array}{l}\text { Rangsangan } \\
\text { baru }\end{array}$ & $\begin{array}{l}\text { Pengalaman } \\
\text { baru }\end{array}$ \\
\hline Umur ayah & $-0,137$ & 0,082 & 0,090 & $-0,204$ & 0,027 & 0,022 & 0,224 & $-0,186$ \\
Umur ibu & $-0,063$ & 0,050 & 0,286 & $-0,018$ & 0,091 & 0,191 & 0,210 & -0121 \\
$\begin{array}{l}\text { Pendidikan } \\
\text { ayah }\end{array}$ & $-0,176$ & $-0,166$ & $-0,213$ & $-0,163$ & $-0,250$ & $-0,045$ & 0,015 & $0,390^{*}$ \\
$\begin{array}{l}\text { Pendidikan } \\
\text { ibu }\end{array}$ & 0,068 & $-0,160$ & $-0,059$ & 0,094 & 0,076 & 0,163 & 0,0157 & 0,337 \\
$\begin{array}{l}\text { Pendapatan } \\
\text { ayah }\end{array}$ & 0,018 & 0,284 & $-0,009$ & 0,210 & 0,096 & 0,165 & $-0,104$ & $-0,140$ \\
$\begin{array}{l}\text { Pendapatan } \\
\text { ibu }\end{array}$ & 0,086 & 0,365 & $0,438^{*}$ & 0,193 & 0,0187 & $0,412^{*}$ & 0,096 & $-0,345$ \\
$\begin{array}{l}\text { Besar } \\
\text { keluarga }\end{array}$ & 0,134 & $-0,292$ & 0,024 & $-0,008$ & 0,074 & $-0,041$ & 0,326 & 0,231 \\
\hline
\end{tabular}

Sedangkan peran ayah adalah pencari nafkah yang penuh pengertian dan memberi rasa aman serta berpartisipasi dalam pendidikan anak dan sebagai pelindung atau tokoh yang tegas, bijaksana dan mengasihi keluarga.

Tabel 10. Korelasi Pengasuhan dengan Kreativitas

\begin{tabular}{lcccccccc}
\hline Variabel & Imajinasi & Lingkungan & Pertanyaan & $\begin{array}{l}\text { Rasa ingin } \\
\text { tahu }\end{array}$ & $\begin{array}{l}\text { Eksperim } \\
\text { en }\end{array}$ & $\begin{array}{l}\text { Rangsan } \\
\text { gan baru }\end{array}$ & $\begin{array}{l}\text { Pengalaman } \\
\text { baru }\end{array}$ & Bosan \\
\hline Pengasuhan & $0,720^{* *}$ & $0,603^{* *}$ & $0,651^{* *}$ & $0,732^{* *}$ & $0,871^{* *}$ & $0,786^{* *}$ & $0,490^{* *}$ & 0,223 \\
\hline
\end{tabular}

Terlihat pada Tabel 10 bahwa pengasuhan yang demokratis pada anak memiliki koefisien korelasi dengan $r=0,720^{* *}$ pengasuhan yang baik dengan bentuk demokratis akan meningkatkan imajinasi (anak dapat bercerita dengan leluasa dengan orang tuanya selain itu juga anak dapat memainkan setiap mainannya sesuai dengan khayalannya). Begitu juga dengan pemberian lingkungan yang baik kepada anak akan meningkatkan kreativitas anak dengan nilai koefisien korelasi $r=0,603^{* *}$ karena orang tua dapat menyediakan ruangan yang baik untuk anak bermain, anak dapat menjelajah lingkungan sekitarnya, anak dapat menyentuh semua benda yang ia temukan di dalam atau di luar ruangan. Selain itu juga terlihat bahwa pengasuhan demokratis dapat menjawab semua pertanyaan anak-anak dengan nilai koefisien korelasi $r=0,651$ dan dapat memenuhi rasa ingin tahu anak dengan koefisien korelasi $r=0,732$. Selain itu dapat dilihat juga bahwa kemampuan eksperimen anak juga berkorelasi dengan pengasuhan dengan nilai $r=0,871$ hal ini dapat dilihat bahwa tingkat kreativitas anak pada kemampuan bereksperimen dimana anak dapat menemukan hal-hal yang baru sesuai dengan rasa ingin tahunya dengan bereksperimen dengan warna, angka, lagu serta bahan alam lainnya sehingga dapat menimbulkan rangsangan baru yang juga berkorelasi dengan nilai $r=0,786$ dengan begitu anak dapat bermain aktif dengan mainan barunya dapat menimbulkan ide-ide atau gagasan baru dan memecahkan masalah dengan baik sehingga menciptakan pengalaman baru yang juga berkorelasi dengan nilai $r=0,490$ yang pada akhirnya dapat meningkatkan prestasi belajar anak serta anak menjadi senang mencari dan memecahkan permasalahan yang dihadapinya. 


\section{SIMPULAN DAN SARAN}

Jenis kelamin dan urutan kelahiran anak dalam keluarga tidak memiliki korelasi dengan gaya pengasuhan yang diterapkan orang tua di rumah, tidak terlihat hubungan antara anak yang lahir lebih awal dengan anak yang lahir kemudian dengan gaya pengasuhan orang tua.

Karakteristik keluarga tidak memiliki korelasi dengan gaya pengasuhan mereka terhadap anak, begitu juga dengan karakteristik anak dengan kreativitas tidak terdapat hubungan yang signifikan antara jenis kelamin dan urutan kelahiran anak dalam keluarga terhadap kemampuan kreativitas anak.

Terdapat hubungan yang signifikan antara pendidikan ayah dengan kreativitas anak dalam menghadapi rasa bosan dan terlihat juga hubungan yang signifikan antara pendapat ibu dalam menjawab pertanyaan-pertanyaan anak dalam kegiatan bermain yang meningkatkan kreativitas sehingga anak mendapatkan rangsangan-rangsangan baru untuk meningkatkan kreativitas mereka.

Terdapat hubungan yang signifikan antara pengasuhan yang diberikan orang tua terhadap kemampuan imajinasi anak, mengenal lingkungan sekitar, menjawab pertanyaan-pertanyaan yang dilontar dari anak, menjawab rasa ingin tahu anak, meningkatkan kemampuan anak untuk bereksperimen, menimbulkan rangsangan-rangsangan baru anak mendapatkan pengalaman baru serta memiliki kemampuan dalam menghadapi rasa bosan.

Berdasarkan hasil temuan yang diperoleh maka penulis mengajukan saran-saran sebagai berikut.

1. Melakukan penelitian lanjutan dengan memperluas ragam responden

2. Melakukan penelitian kembali untuk mengetahui ada tidaknya perbedaan pola asuh dan kreativitas dengan melihat tiga jenis pola asuh (authoritative, demonstratif, dan permisif)

3. Memberikan informasi kepada orang tua untuk tidak membedakan perlakuan pengasuhan antara anak laki-laki dan anak perempuan.

\section{REFERENSI}

Brown. F.J. (1961). Educational psychology, 2nded. New Jersey: Prentice Hall Engelwood. Hurlock, Elizabeth. (1991). Perkembangan anak (Jilid 2 edisi 6). Jakarta: Erlangga.

Jalal, F. (2003). Kebijakan makro pendidikan anak usia dini Indonesia. Jakarta: Buletin PADU Edisi Khusus.

Munadi, S. (1987). Sifat tahu, kreativitas dan memotivasi berprestasi praktek dalam pencapaian prestasi. Yogyakarta: IKIP.

Munandar, Utami. (2004). Pengembangan kreativitas anak berbakat, Jakarta: Rineka Cipta.

Munandar, U. (1988). Kreativitas sepanjang masa. Jakarta: Pustaka Sinar Harapan.

Patmonodewo, S. (2003). Pendidikan anak prasekolah. Jakarta: PT Rineka Cipta.

Semiawan, Conny. (1999). Pendekatan keterampilan proses. Jakarta: Gramedia.

Sitorus, M. (1988). Sosiologi. Bandung: Cahaya Budi.

Suparlan, Parsudi. (1993). Kemiskinan di perkotaan. Jakarta: Yayasan Obor.

Sumardjan, Selo. (1983). Kreativitas, suatu tinjauan dari sudut sosiologi. Jakarta: Dian Rakyat.

Stewart \& Koch. (1983). Chidren development throught adolescence. Canada: John Wiley and Sons, Inc. 